\title{
СПЕЦИФИКА РАЗВИТИЯ СОЦИАЛЬНОГО ПРЕДПРИНИМАТЕЛЬСТВА В 21 ВЕКЕ
}

Котов Евгений Сергеевич аспирант Научный руководитель: Дмитриев Антон Геннадиевич к.э.н., доцент МФПУ «Синергия»

\begin{abstract}
Аннотация: В настоящее время развитие социального предпринимательства набирает обороты во всем мире. Тренд на развитие такого рода предпринимательства сегодня можно увидеть во всем мире. В данной статье мы рассмотрим, с чем сталкивается социальный бизнес в современное время и как решает те задачи, с которыми он сталкивается.
\end{abstract}

Ключевые слова: социальное предпринимательство, предпринимательство, экономика, современность, инновации, развитие.

\section{THE SPECIFICS OF THE DEVELOPMENT OF SOCIAL ENTREPRENEURSHIP IN THE 21ST CENTURY}

\section{Kotov Evgeny Sergeevich Dmitriev Anton Gennadievich}

\begin{abstract}
Currently, the development of social entrepreneurship is gaining momentum all over the world. The trend for the development of this kind of entrepreneurship can be seen all over the world today. In this article, we will look at what social business is facing in modern times and how it solves the problems it faces.
\end{abstract}

Key words: Social entrepreneurship, entrepreneurship, economy, modernity, innovation, development.

Социальное предприятие - это оператор социальной экономики, основной целью которого является оказание социального воздействия, а не получение прибыли для своих владельцев или акционеров. Он работает, предоставляя товары и услуги для рынка в предпринимательской и 
инновационной манере, и использует свою прибыль в первую очередь для достижения социальных целей. Он управляется открыто и ответственно и, в частности, вовлекает сотрудников, потребителей и заинтересованные стороны, которых затрагивает его коммерческая деятельность.

Мы используем термин «социальное предприятие» для обозначения следующих видов бизнеса.

- Те, для кого социальная или общественная цель общего блага является причиной коммерческой деятельности, часто в форме высокого уровня социальных инноваций.

- Те, чья прибыль в основном реинвестируется для достижения этой социальной цели.

- Те, в которых метод организации или система собственности отражают миссию предприятия, используя демократические принципы или принципы участия или ориентируясь на социальную справедливость.

Единой организационно-правовой формы социальных предприятий не существует. Многие социальные предприятия работают в форме социальных кооперативов, некоторые зарегистрированы как частные компании с ограниченной ответственностью, некоторые являются взаимными, и многие из них являются некоммерческими организациями, такими как страховые общества, ассоциации, добровольные организации, благотворительные организации или фонды.

Несмотря на свое разнообразие, социальные предприятия в основном работают в следующих 4 областях:

- Рабочая интеграция - обучение и интеграция людей с ограниченными возможностями и безработных

- Индивидуальные социальные услуги - здоровье, благополучие и медицинское обслуживание, профессиональная подготовка, образование, медицинские услуги, услуги по уходу за детьми, услуги для пожилых людей или помощь малоимущим.

- Местное развитие неблагополучных районов - социальные предприятия в отдаленных сельских районах, схемы развития/восстановления микрорайонов в городских районах, помощь в целях развития и сотрудничество в целях развития с третьими странами

- Прочее, включая переработку, защиту окружающей среды, спорт, искусство, культуру или сохранение исторического наследия, науку, исследования и инновации, защиту прав потребителей и любительский спорт. 
Социальные предприятия - это растущий бизнес. Более чем десятилетние исследования доказывали это снова и снова. Они оптимистичны и амбициозны и рассчитывают продолжить этот рост в предстоящем году. Несмотря на экономические и политические потрясения последних лет, социальные предприятия увеличивают свои размеры, нанимают больше сотрудников и усиливают свое влияние. Этот успех был достигнут благодаря тому, что социальные предприятия превосходят своих коллег в частном секторе за счет более высокого уровня

инноваций, инвестиций в людей и привлечения персонала и сообществ. Общественный предприятия демонстрируют, что бизнес, ориентированный на социальную и экологическую миссию, может обеспечить лучшие экономические показатели.

ОСНОВНЫЕ ВЫВОДЫ:

Растет число социальных предприятий: $42 \%$ социальных предприятий моложе 5 лет. Трем из десяти социальных предприятий исполнилось три года или меньше, что даже выше, чем ранее, что свидетельствует о том, что волна стартапов, выявленная в предыдущих исследованиях, продолжает расти.

Рост в размерах оборота: 52\% социальных предприятий увеличили свой оборот за последние 12 месяцы. Это выше, чем в 2017 году, и намного выше, чем у $34 \%$ малых и средних предприятий, у которых наблюдается рост.

Независимые предприятия: Социальные предприятия - это предприятия, которые получают свой доход за счет торговли, конкурируя на рынке - 77\% социальных предприятий зарабатывают более $75 \%$ своего дохода от торговли, по сравнению с нашим предыдущим опросом.

Инновации: доля социальных предприятий, внедряющих новый продукт или услугу, в 2019 году составила 56\%, что снова выше, чем в предыдущие годы.

Коммерчески успешные: $48 \%$ социальных предприятий получили прибыль в прошлом году, показатель безубыточности составил $27 \%$, а процент потерь был ниже, чем в предыдущих исследованиях. Чем дольше существует социальное предприятие, тем больше вероятность того, что оно получит прибыль.

Социальная справедливость.

В отличие от "традиционного" бизнеса, рост которого может привести к большему неравенству, ценность, создаваемая социальным предприятием, разделяется всеми. Социальные предприятия реинвестируют свою прибыль 
обратно в выполнение своей миссии. Выгоды распределяются между общинами, часто в наших наиболее неблагополучных районах. Социальные предприятия решают основные социальные проблемы, с которыми мы сталкиваемся, включая борьбу с гендерным и расовым неравенством благодаря лидерству женщин и лидеров чернокожих и этнических меньшинств.

Основные выводы:

- $40 \%$ социальных предприятий возглавляются женщинами, что более чем в два раза превышает показатели МСП в более широком масштабе (17\%). Два из пяти (42\%) имеют большинство женской рабочей силы; на $13 \%$ женщины составляют всю рабочую силу. 34 процента социальных предприятий, возглавляемых женщинами, моложе трех лет, по сравнению с $28 \%$ возглавляют мужчины.

- $13 \%$ социальных предприятий возглавляются представителями этнических меньшинств, а 35\% есть директора, которые делают социальные предприятия гораздо более представительными для населения в целом. $42 \%$ социальных предприятий, возглавляемых представителями этнических меньшинств, моложе трех лет, что свидетельствует о динамичности этой части сектора.

- $73 \%$ респондентов сообщили, что их организация работает с лицами, находящимися в неблагоприятном положении, также по сравнению с предыдущими годами, в то время как $42 \%$ сообщили, что их организация стремится их трудоустроить.

- Три четверти (76\%) респондентов заявили, что они являются работодателями с прожиточным минимумом.

Экологическая ответственность.

Социальные предприятия реагируют на масштабы климатического кризиса так, как многие другие предприятия не реагируют. Социальные предприятия признают, что в будущем воздействие на окружающую среду должно иметь больший вес и что необходимо поощрять персонал действовать как можно более ответственно в отношении окружающей среды. Тем не менее социальные предприятия продолжают сталкиваться с целым рядом проблем, препятствующих их росту, не только финансовых, но и операционных, экономических и нормативных. Они нуждаются в поддержке со стороны правительства, чтобы соответствовать приверженности своих клиентов и энергии их лидеры, если они собираются продолжать прокладывать путь к более процветающему, справедливому и экологичному будущему. 
КАСАЮЩИЕСЯ ОКРУЖАЮЩЕЙ СРЕДЫ: Почти девЯть из десяти социальных предприятий (88\%) сообщают, что их организация активно стремится минимизировать свое воздействие на окружающую среду, по сравнению с нашим предыдущим опросом.

СТИМУЛИРОВАНИЕ УСТОЙЧИВОГО РАЗВИТИЯ: 65\% социальных предприятий ожидают, что в ближайшие два-три года в их организации будет уделяться больше внимания устойчивым и экологически чистым процессам. Это значительно выше, чем у МСП в более широком масштабе (49\%).

БАЛАНС МЕЖДУ ПРИБЫЛЬЮ И ПЛАНЕТОЙ: 75\% социальНЫХ предприятий заявили, что при принятии решений о закупках они считают экологические соображения равными или более важными, чем затраты. Это сопоставимо с 24\% владельцев малого и среднего бизнеса.

\section{Список литературы}

1. Introduction to Social Entrepreneurship, Chahine T., 2016.

2. Social Entrepreneurship, Paramasivan C., 2016. 